\title{
Role of high mountain areas in catchment hydromineral resources - Northern/Central Portugal: environmental issues
}

J. M. Marques ${ }^{1}$, P. M. Carreira ${ }^{2}$, J. Espinha Marques ${ }^{3}$, H. I. Chaminé, ${ }^{4,5}$, P. E. Fonseca ${ }^{6}$, F. A. Monteiro Santos ${ }^{7}$, E. Almeida ${ }^{7,8}$, R. Gonçalves ${ }^{7,8}$, P. G. Almeida ${ }^{9}$, A. Gomes ${ }^{10}$, J. Teixeira ${ }^{4,5}$, J. M. Carvalho ${ }^{4,5} \&$ F. T. Rocha ${ }^{5}$

${ }^{1}$ Instituto Superior Técnico, Portugal

${ }^{2}$ Instituto Tecnológico e Nuclear, Portugal

${ }^{3}$ Faculdade de Ciências da Universidade do Porto (CGUP), Portugal

${ }^{4}$ Instituto Superior de Engenharia do Porto (LABCARGA), Portugal

${ }^{5}$ Universidade de Aveiro (MIA), Portugal

${ }^{6}$ Faculdade de Ciências da Universidade de Lisboa (CGUL), Portugal

${ }^{7}$ Centro de Geofisica da Universidade de Lisboa, Portugal

${ }^{8}$ Instituto Politécnico de Tomar, Portugal

${ }^{9}$ Universidade da Beira Interior, Portugal

${ }^{10}$ Faculdade de Letras da Universidade do Porto, Portugal

\begin{abstract}
This study summarizes the results of geological, geomorphological, tectonic, geochemical, geophysical, hydrogeological and isotopic techniques in hydromineral resources assessment (issue temperature between $27^{\circ} \mathrm{C}$ and $45^{\circ} \mathrm{C}$ ). Two case studies are presented: i) Serra da Estrela mountain region, the highest mountain in Portuguese mainland and ii) Serra do Marão mountain region. A special emphasis is dedicated to the recharge and discharge processes and the role of snowmelt as a source of hydromineral resources. Since local Spas are particularly dependent on water quality, the existence of mixing between hydromineral waters and local shallow groundwaters is also considered.

Keywords: geochemistry, isotopes, geophysics, tectonics, high mountain areas hydrogeology, hydromineral resources, environmental issues, Portugal.
\end{abstract}




\section{Introduction}

Mountain areas represent some of the blackest "black boxes" in the hydrological cycle (Chalise [1]). The complex role of soils, geomorphology, geology, climate and land use on the hydrology of mountain areas, are rather difficult to model. Nevertheless, mountain river basins provide the finest opportunity to increase knowledge on the relationship between those variables as well as their impacts on the water quality at different altitude zones [1]. This study attempts to present, under an environmental multidisciplinary approach, the assessment of two hydromineral systems in different mountain regions, located in Central/Northern Portugal, fig. 1, highlighting the environmental problems. Both areas present particular climatic, geomorphologic and geotectonic characteristics that contribute to control the recharge/discharge processes as well as the flow paths.

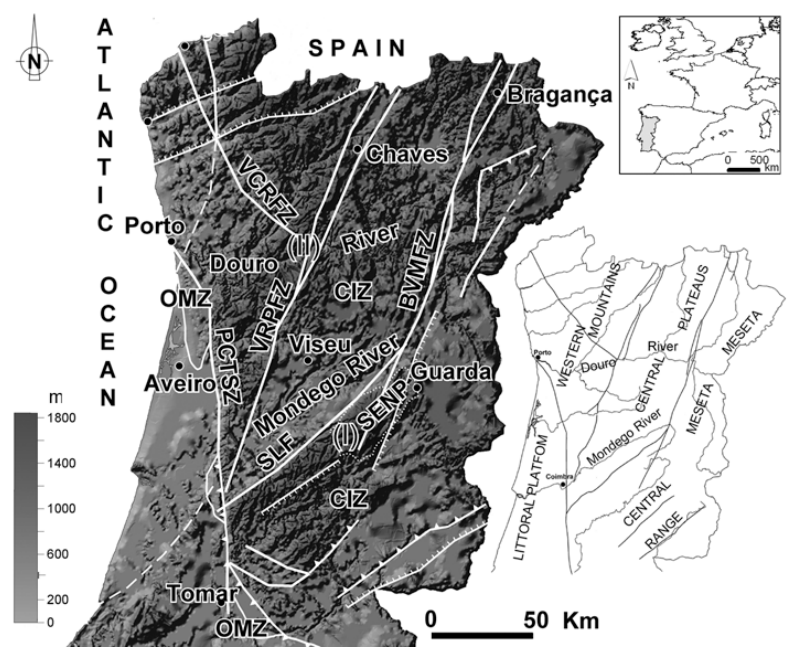

Figure 1: $\quad$ Morphotectonic features at Serra da Estrela National Park (SENP) (I) and Caldas do Moledo (II) mountain regions. Explanation: PCTSZ: Porto-Coimbra-Tomar strike-slip shear zone; VCRFZ: Vigo-Vila Nova de Cerveira-Régua fault zone; VRPFZ: VerinRégua-Penacova fault zone; BVMFZ: Bragança-VilariçaManteigas fault zone; SLF: Seia-Lousã fault zone; CIZ - CentralIberian Zone, OMZ - Ossa-Morena Zone.

At Serra da Estrela National Park (SENP) a special emphasis will be dedicated to: i) the recharge and discharge processes, ii) the role of snowmelt as a source of groundwater resources and iii) the local environmental issues which could affect the surface water-shallow groundwater-groundwater interactions.

At Caldas do Moledo region, coupled geomorphological, geotectonical, geochemical and isotopic data made it possible to improve knowledge on i) the hydrogeological conceptual model of the discharge area, based on the relations 
between shallow groundwaters and deep mineral waters, and ii) the local anthropogenic impacts on the groundwaters.

\section{Climate, geomorphology and geology}

\subsection{Serra da Estrela region (Central Portugal)}

The relief of the study region consists mainly of two major plateaus ( $c a$. 1450$1993 \mathrm{~m}$ a.s.1.), separated by the NNE-SSW valley of Zêzere River (Vieira [2]). Late Pleistocene glacial landforms and deposits are a distinctive feature of the upper Zêzere catchment, fig. 2, since the bulk plateau area was glaciated [2]. The ice sheet that covered most northern and central Europe 18,000 years BP did not reach the study region, where only mountain glaciers were present.

Climate has Mediterranean features: mean annual precipitation reaches 2500 $\mathrm{mm}$ in the highest areas, and is mainly controlled by slope orientation and altitude. Mean annual air temperature is below $7^{\circ} \mathrm{C}$ in most of the plateau areas and, in the highest sites (e.g. Torre surroundings) it may be as low as $4^{\circ} \mathrm{C}$ (Vieira and Mora [3]).

Serra da Estrela Mountain is located in the so-called Central-Iberian Zone of the Iberian Massif (Ribeiro et al [4]), mainly composed by Variscan granitic rocks and Precambrian-Cambrian metasedimentary rocks, as well as alluvia and Quaternary glacial deposits.

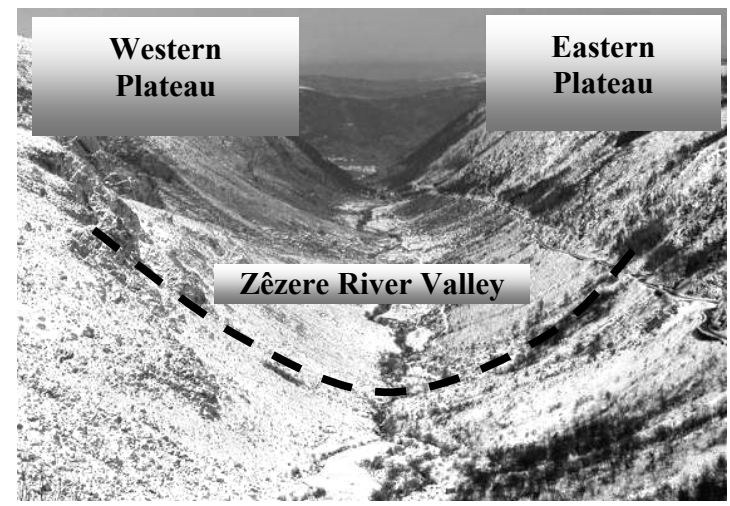

Figure 2: The U-shaped Zêzere River Valley (Eastern and Western Plateaus).

\subsection{Caldas do moledo region (Northern Portugal)}

The main geomorphologic feature of the Caldas do Moledo region is the Douro River valley, fig.3a, bordered by the Marão Mountain ridge (ca. $1415 \mathrm{~m}$ a.s.1.) to the north and by the Meadas Mountain ridge to the south. The average annual temperature is about $15^{\circ} \mathrm{C}$. The climate in the Douro region is influenced by the Marão Mountain which acts as a barrier that protects the region from the humid 
west winds from the Atlantic Ocean. Annual rainfall ranges from $1200 \mathrm{~mm}$ to $380 \mathrm{~mm}$. It is heavier in December and January and, during the wettest months, it may be as low as $7 \mathrm{~mm}$ (D.G.R.A.H. [5]).

Caldas do Moledo region is also located in the Central-Iberian Zone of the Iberian Massif [4]. The most abundant lithotypes are metasedimentary rocks of lower Cambrian age (Schist-Greywacke Complex, Douro Group), also including significant aplite and pegmatite veins (Teixeira et al [6]), suggesting the existence of an important underlying granitic rock mass Espinha (Marques et al [7]).

The most important tectonic structures in the region are the NNE-SSW VerinRégua-Penacova fault zone (VRPFZ), where the hydromineral resources issue, see fig. 1, and the WNW-ESE to NW-SE Vigo-Vila Nova de Cerveira-Régua fault zone, VCRFZ [7].

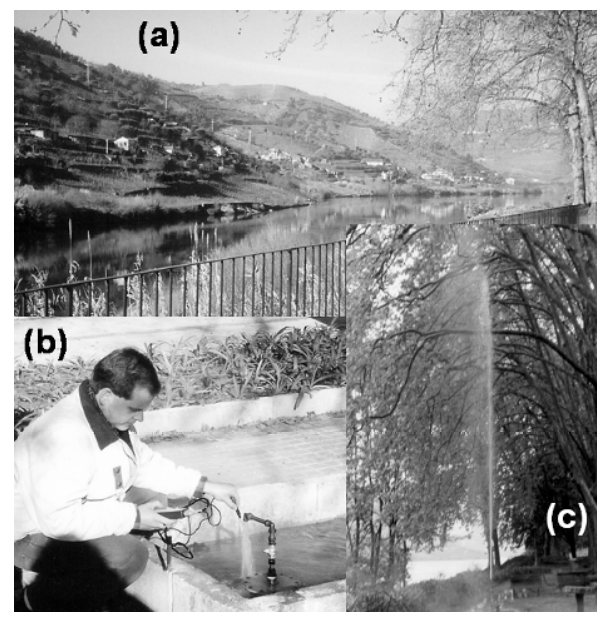

Figure 3: Caldas do Moledo: (a) Douro River valley; (b) mineral water sampling at the $\mathrm{Spa}-(\mathrm{c})$ artesian borehole $\mathrm{AC} 1\left(45^{\circ} \mathrm{C}\right)$.

\section{Research methods}

Three water-types were sampled: river waters, shallow cold groundwaters (spring waters - so called "normal" waters) and mineral waters (e.g. at Caldas de Manteigas and Caldas do Moledo Spas). Temperature $\left({ }^{\circ} \mathrm{C}\right), \mathrm{pH}$ and electrolytical conductivity (EC: in $\mu \mathrm{S} / \mathrm{cm}$ ) were determined in situ, fig. 4 . Water samples were specifically treated - ultrafiltration. Total alkalinity was measured a few hours after collection. The chemical analyses of the waters were performed at the Laboratório de Mineralogia e Petrologia of Instituto Superior Técnico (LAMPIST) by the following methods: atomic absorption spectrometry for $\mathrm{Ca}^{2+}$ and $\mathrm{Mg}^{2+}$; emission spectrometry for $\mathrm{Na}^{+}, \mathrm{K}^{+}$and $\mathrm{Li}^{+}$; colorimetric methods for $\mathrm{SiO}_{2}$ and $\mathrm{F}^{-}$; ion chromatography for $\mathrm{SO}_{4}{ }^{2-}, \mathrm{NO}_{3}{ }^{-}$and $\mathrm{Cl}^{-}$; potentiometry for alkalinity, here referred to as $\mathrm{HCO}_{3}{ }^{-}$. For $\mathrm{HS}^{-}$determinations, $\mathrm{CdS}$ was titrated 
by potentiometry with sodium thiosulphate. The $\delta^{2} \mathrm{H}$ and $\delta^{18} \mathrm{O}$ measurements (vs. V-SMOW) were performed by mass spectrometry (SIRA 10-VG ISOGAS) at the Instituto Tecnológico e Nuclear (ITN) following the analytical methods of Epstein and Mayeda [8] and Friedman [9] (accuracy of $\pm 1.0 \%$ for $\delta^{2} \mathrm{H}$ and \pm $0.1 \%$ for $\delta^{18} \mathrm{O}$ measurements). The ${ }^{3} \mathrm{H}$ concentrations in the waters (in TU) were determined at ITN, using electrolytical enrichment followed by liquid scintillation counting method (PACKARD Tri-Carb 2000 CA/LL (standard deviation around $\pm 0.6 \mathrm{TU})$.

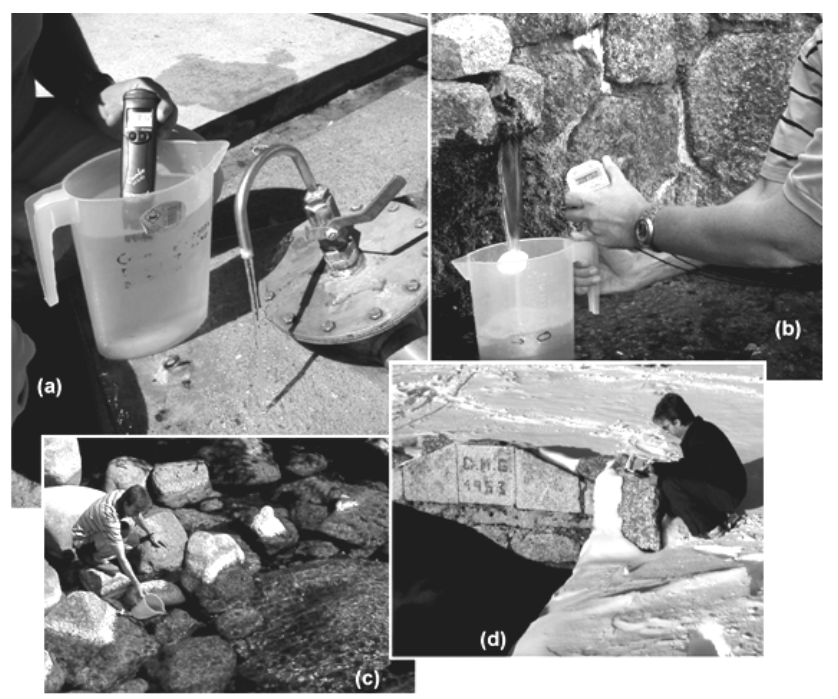

Figure 4: Sampling sites at Serra da Estrela Natural Park: (a) Caldas de Manteigas Spa, mineral waters - artesian borehole AC2 $\left(42^{\circ} \mathrm{C}\right)$; (b) Jonja spring; (c) Zêzere River; (d) Vale Formoso spring.

\section{Results and discussion}

\subsection{Serra da Estrela region}

Most "normal" groundwaters belong to the $\mathrm{Na}-\mathrm{Cl}$ and $\mathrm{HCO}_{3}-\mathrm{Na}$ facies, with low TDS, considered as good signatures of local recharge and hydrolysis of $\mathrm{Na}-$ plagioclases, respectively. The high $\mathrm{Na}-\mathrm{Cl}$ concentrations found in some of the waters of this group (e.g. Espinhaço de Cão and N. Sto. António, see fig. 5) could be ascribed to the local use of $\mathrm{NaCl}$ to promote snowmelt in the roads during the winter season. Mineral waters from Caldas de Manteigas Spa are characterised by the following main features: high $\mathrm{pH}$ values $(\approx 9)$, EC values around $300 \mu \mathrm{S} / \mathrm{cm}$, the presence of reduced species of sulphur $\left(\mathrm{HS}^{-} \approx 1.7 \mathrm{mg} / \mathrm{L}\right)$, silica values (around $50 \mathrm{mg} / \mathrm{L}$ ) representing a significant \% of TDS values and high $\mathrm{F}^{-}$concentrations (up to $7 \mathrm{mg} / \mathrm{L}$ ), indicating that the reservoir rock should be mainly the granite. The strong $\mathrm{HCO}_{3}-\mathrm{Na}$ signatures of Caldas de Manteigas mineral waters can be clearly seen in the Stiff diagram of fig. 5 . 


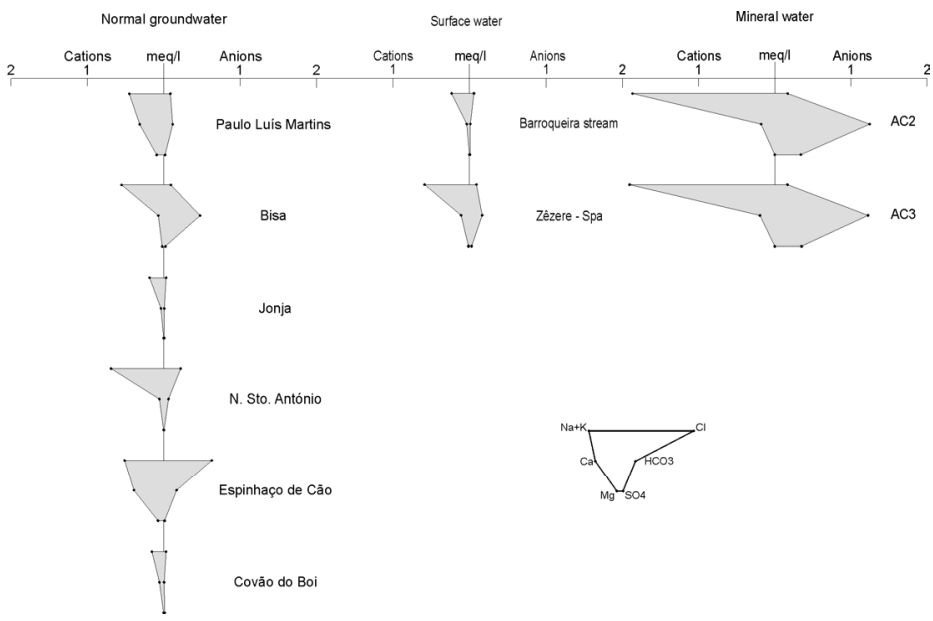

Figure 5: Representative Stiff diagrams of the studied waters. Adapted from Espinha Marques [10].

Since the isotopic content of snow pack is mainly controlled by variations in the isotopic content of individual precipitation events (Kendall and McDonnell [11]), sampling of melt water, instead of snow, is generally suggested for hydrological studies. Therefore, fieldwork campaigns at Serra da Estrela were performed in April (after the beginning of the snowmelt period) and September (the end of the summer season).

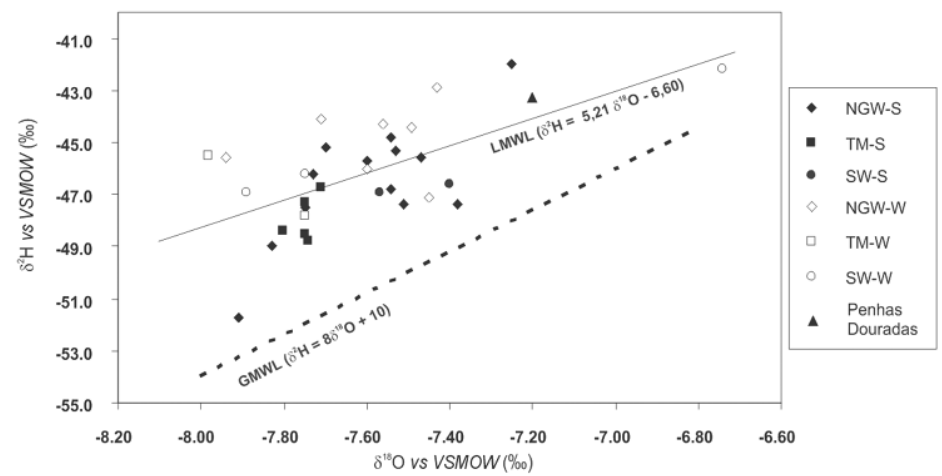

Figure 6: $\quad \delta^{2} \mathrm{H} v s . \delta^{18} \mathrm{O}$ diagram. LMWL - Local Meteoric Water Line; NGW - normal groundwaters; TM - mineral waters; SW - surface water; S summer; W winter; $\boldsymbol{\Delta}$ - P. Douradas precipitation. Adapted from [10].

A progressive depletion in heavy isotopes, fig. 6, ascribed to the recharge altitude of the sampling sites was observed (the Global Meteoric Water Line GMWL - is shown as reference). 
Two important isotopic signatures, fig. 6, should be highlighted: i) no influence of a lighter isotope component was detected in the groundwater samples from winter (April) campaigns, and ii) a deviation in the isotopic composition of the mineral water sample collected from borehole AC2 (winter 2004). The first signature can be explained by a high residence time leading to a mixing process between different groundwater bodies, with the tendency to the homogenisation of the isotopic composition. This process should occur mainly in the porous medium (dominated by alluvia and Quaternary glacial deposits) and the most weathered granitic rocks. In the second situation, the most reliable explanation should be attributed to an analytical error.

The recharge altitude of the hydromineral system was estimated by sampling spring waters at different altitudes. The $\delta^{18} \mathrm{O}$ isotopic gradient was $-0.14 \%$ oo $/ 100$ $\mathrm{m}$ of altitude [10]. Therefore, the upper valley of Zêzere River, should be a potential catchment area of Caldas de Manteigas hydromineral system [10].

Since Nave de Santo António col (near Torre area), located at an elevation of $1540 \mathrm{~m}$ a.s.1., is one of the main potential recharge areas, three VES with an $\mathrm{AB} / 2$ spacing varying between $1 \mathrm{~m}$ and $200 \mathrm{~m}$ have been carried out in the southern part of basin. The VES soundings were inverted assuming a layered earth model and the results are presented in fig. 7. Preliminary results show that it is difficult to have a clear picture of the basin. Nevertheless, one can consider that the fill $(20-40 \mathrm{~m})$ is dominated by sand strata with different granulometry, and other particulate rock materials (e.g. blocks, etc.). The deeper part of the basin (resistivity values smaller than 2000 ohm-m) has a non-uniform topography and may consist of granite with different degrees of weathering [10].

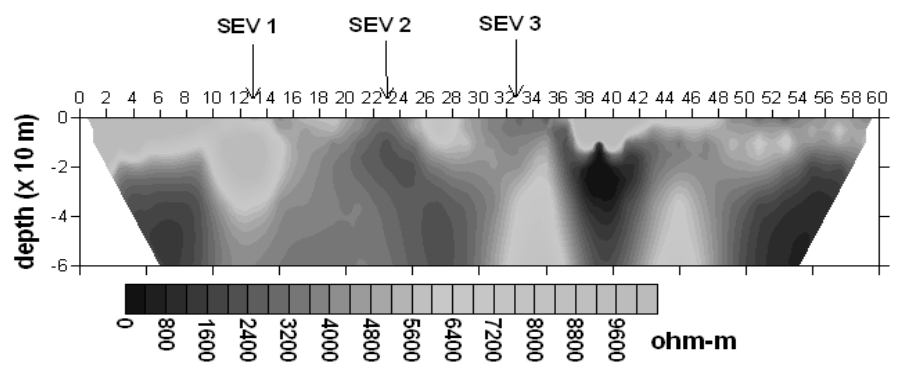

Figure 7: Apparent resistivity pseudo-section of the dipole-dipole profile. Adapted from [10].

\subsection{Caldas do Moledo region}

At Caldas do Moledo region, spring and borehole mineral waters emerge with temperatures between $27^{\circ} \mathrm{C}$ and $45^{\circ} \mathrm{C}$. Their geochemical signatures are quite similar to those of Caldas de Manteigas Spa waters: $\mathrm{pH}$ values between 8.0 and 9.0, TDS values in the range of 200 to $350 \mathrm{mg} / \mathrm{L}, \mathrm{HCO}_{3}$ is the dominant anion, $\mathrm{Na}$ is the dominant cation, the presence of reduced species of sulphur ( $\mathrm{HS}^{-} \approx 2.5$ $\mathrm{mg} / \mathrm{L}$, high silica values $(\approx 50 \mathrm{mg} / \mathrm{L})$, and $\mathrm{F}^{-}$concentrations up to $10 \mathrm{mg} / \mathrm{L}$. 
These geochemical signatures indicate that in Caldas de Manteigas hydromineral system the reservoir rock should also be the granite.

All water samples lie on or close to the GMWL indicating that they have a meteoric origin, fig. 8. The Local Meteoric Water Line (LMWL) $\delta^{2} \mathrm{H}=$ $(9.28 \pm 0.84) \delta^{18} \mathrm{O}+(20.21 \pm 4.20)$ was established using all the available data from local mineral and shallow groundwater systems Marques et al [12]. From the observation of the diagram of fig. 8 one can consider that i) no oxygenisotope shift due to water-rock interaction at high temperatures was found, and ii) the contribution of Douro River waters to the recharge of the hydromineral system should be inexistent.

The altitude dependence of the isotopic composition of Caldas do Moledo hydromineral system was determined by $\delta^{18} \mathrm{O}$ values of springs in the Spa area and its bordering mountains. As stated by Marques et al [13] the isotopic gradient for $\delta^{18} \mathrm{O}$ was $-0.12 \% / 100 \mathrm{~m}$ of altitude, reflecting the influence of geographical parameters depending on the local climate and topography.

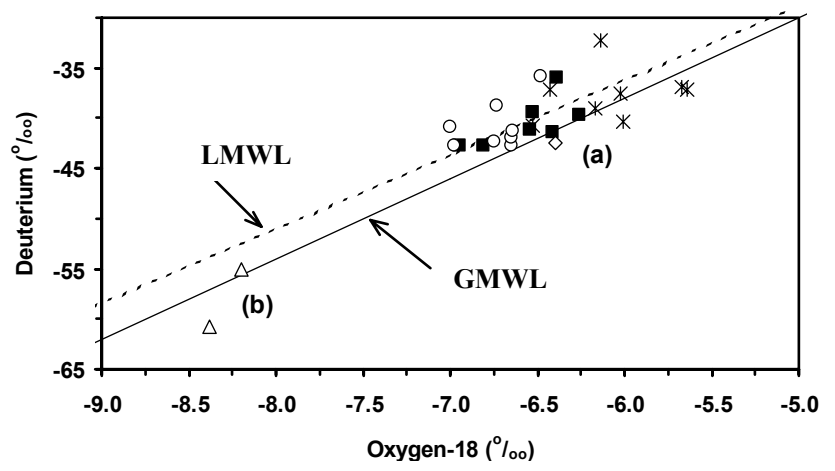

Figure 8: $\quad \delta^{2} \mathrm{H}$ vs $\delta^{18} \mathrm{O}$ plot for water samples from Caldas do Moledo area. Taken from [12]. ( $\bigcirc)$ mineral borehole waters; ( $\bullet$ ) mineral spring waters; $(*)$ shallow cold spring waters; $(\triangle)$ Douro River waters; $(\diamond)$ Porto precipitation.
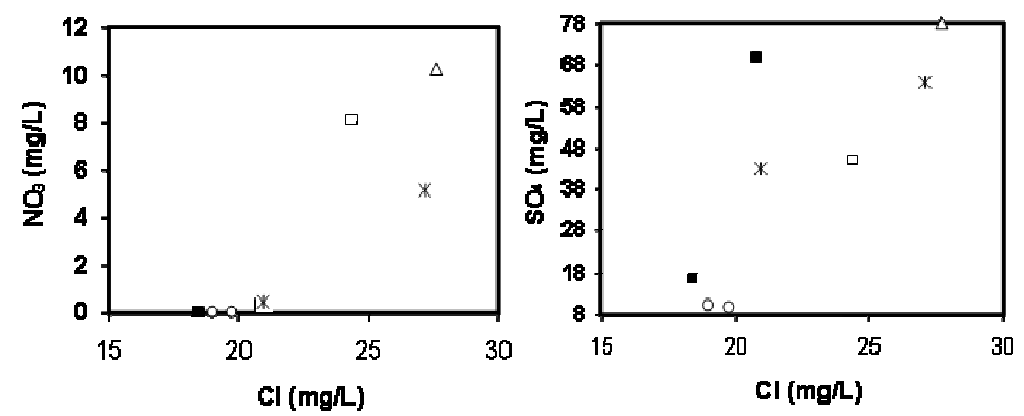

Figure 9: $\mathrm{NO}_{3}^{-}$vs. $\mathrm{Cl}$ and $\mathrm{SO}_{4}{ }^{2-}$ vs. $\mathrm{Cl}$ diagrams for water samples from Caldas do Moledo area: symbols as in fig. 8; ( $\square$ ) a mineral spring with distinct geochemical and isotopic signatures [14]. 
Espinha Marques et al [14] have showed a trend towards high $\mathrm{SO}_{4}{ }^{2-}$ and $\mathrm{NO}_{3}{ }^{-}$ concentrations as one passes from the hydromineral system to the shallow cold groundwaters, fig. 9. This trend supports the hypothesis of mixing between hydromineral fluids with local shallow groundwaters characterised by relatively high $\mathrm{K}^{+}, \mathrm{Ca}^{2+}, \mathrm{NO}_{3}{ }^{-}, \mathrm{SO}_{4}{ }^{2-}$ and $\mathrm{Cl}^{-}$concentrations (usual components of the most common fertilisers used in the vineyards, at the northern part of the country). Nevertheless, mineral waters from boreholes AC1 and AC2 do not show any evidence of anthropogenic contamination.

\section{Conceptual models, environmental issues and outlook}

Regarding Caldas de Manteigas hydromineral system, the Bragança-VilariçaManteigas fault zone, see fig.1, plays an important role in conducting the infiltrated meteoric waters towards the discharge zone, ascribed to the intersection of the main NNE-SSW structure with the conjugate WNW-ESE configuration, near Caldas de Manteigas Spa. The main environmental problem detected is ascribed to local use of $\mathrm{NaCl}$ to promote snowmelt in the roads during the winter season. In the case of Caldas do Moledo hydromineral system, the recharge area is located on the WNW-ESE Vigo-Vila Nova de CerveiraRégua fault zone, which conducts the infiltrated meteoric waters towards the Verin-Régua-Penacova fault zone, see fig. 1, responsible for creating the mineral waters ascent. Geochemical and isotopic results point out to the existence of anthropogenic contamination of some mineral spring waters related to the intense use of fertilizers in the Portwine vineyards. This paper describes rather similar mineral waters, with analogous conceptual models but different environmental issues. The data obtained was used to define areas at higher contamination risk for further detailed multidisciplinary studies.

\section{Acknowledgements}

This study was granted by the Portuguese Foundation for Science and Technology (FCT) and FEDER EU funds, contract POCTI/CTA/44235/02.

\section{References}

[1] Chalise, S.R., High mountain hydrology in changing climates: perspectives from the Hindu Kush-Himalayas. Developments in hydrology of mountain areas. Proceedings of the FRIEND AMHY Annual Report No.4, eds. L.Molnár, P. Miklánek \& I. Mészáros, I., IHP-V, Technical Documents in Hydrology 8, pp. 23-31, 1994.

[2] Vieira, G.T., Geomorfologia dos planaltos e altos vales da Serra da Estrela. Ambientes frios do Plistocénico Superior e dinâmica actual. Universidade de Lisboa, 724 pp. + 1 map (Unpublished PhD Thesis - in Portuguese), 2004. 
[3] Vieira, G.T. \& Mora, C., General characteristics of the climate of the Serra da Estrela. Glacial and Periglacial Geomorphology of the Serra da Estrela. Guidebook for the field-trip, IGU Commission on Climate Change and Periglacial Environments, ed. Vieira, G.T., CEG and Department of Geography, Univ. of Lisbon, pp. 26-36, 1998.

[4] Ribeiro, A., Kullberg, M.C., Kullberg, J.C., Manuppela, G., \& Phipps, S., A review of Alpine tectonics in Portugal: foreland detachment in basement and cover rocks. Tectonophysics, 184, pp. 357-366, 1990.

[5] D.G.R.A.H. [Direcção Geral dos Recusros e Aproveitamentos Hidráulicos], (eds). Monografias Hidrológicas dos Principais Cursos de Água de Portugal Continental (in Portuguese), Lisboa, 1986.

[6] Teixeira, C., Fernandes, A.P. \& Peres, A., Notícia explicativa da Carta Geológica de Portugal na escala 1/50 000. Folha 10-C (Peso da Régua). Serviços Geológicos de Portugal, Lisboa, pp. 1-60, 1967.

[7] Espinha Marques, J., Chaminé, H.I., Carvalho, J.M. \& Borges, F.S., Tectónica regional do sector de Caldas do Moledo-Granjão-Cidadelhe (Falha de Penacova-Régua-Verín, N de Portugal): implicações no controlo das emergências hidrominerais. Comunicações do Instituto Geolológico e Mineiro, 88, pp. 203-212, 2001.

[8] Epstein, S. \& Mayeda, T., Variation of ${ }^{18} \mathrm{O}$ content of waters from natural sources. Geochimica et Cosmochimica Acta, 4, pp. 213-224, 1953.

[9] Friedman, I., Deuterium content of natural waters and other substances. Geochimica et Cosmochimica Acta, 4, pp. 89-103, 1953.

[10] Espinha Marques, J., Contribuição para o conhecimento da hidrogeologia da região do Parque Natural da Serra da Estrela (Sector de Manteigas Nave de Santo António - Torre), Universidade do Porto, 466 pp, (unpublished $\mathrm{PhD}$ thesis - in Portuguese), 2007.

[11] Kendall, C. \& McDonnell, J.J., (eds). Isotope tracers in catchment hydrology. Elsevier, 1998.

[12] Marques, J.M., Espinha Marques, J., Carreira, P.M., Graça, R.C., AiresBarros, L., Carvalho, J.M., Chaminé, H.I. \& Borges, F.S., Geothermal fluids circulation at Caldas do Moledo area, Northern Portugal: geochemical and isotopic signatures. Geofluids, 3, pp. 189-201, 2003.

[13] Marques, J.M., Aires-Barros, L. \& Graça, R.C., Isotopic and chemical signatures of low-temperature sulphurous mineral waters (northern Portugal): preliminary results. Geothermal Resources Council Transactions, 23, pp. 327-332, 1999.

[14] Espinha Marques, J., Marques, J.M., Chaminé, H.I., Gomes, A.A., Fonseca, P.E., Carvalho, J.M., Carreira, P.M., Graça, R.C., Aires-Barros, L. \& Borges, F.S., Poço Quente thermal spring (Granjão-Caldas do Moledo, Northern Portugal): morphostructure, geochemistry and hydrogeology. Cadernos Lab. Xeolóxico de Laxe, Revista de Xeoloxía Galega e do Hercínico Peninsular, Spain, 28, pp. 147-172, 2003. 